\title{
About the Application of Computer Technology in Internet Finance -- based on the Analysis of the Impact of Venture Capital on Capital Overoffering of listed Companies in Financial Investment
}

\author{
Shixin Zhou \\ Jiangxi University of Traditional Chinese Medicine,Nanchang,Jiangxi,330004,China
}

\begin{abstract}
With the further development of computer technology, the era of Internet finance has arrived. Computer technology plays an important role in promoting the development of Internet finance and has also become an important basis for the development of Internet finance. The application of computer technology is conducive to the further improvement of the Internet financial system and the better promotion of transaction efficiency. However, there are also many risks in this process. In the field of financial investment, venture capital plays a very important role in the overoffering of listed companies. In this regard, we should not only improve and upgrade the computing technology, but also control the risks existing in the Internet finance. Therefore, this paper mainly discusses the application of computer technology in Internet finance, and from the perspective of the impact of venture capital in financial investment on capital overoffering of listed companies for in-depth discussion.
\end{abstract}

\section{Literature Review}

In recently years, IPO over-raised capital and venture captital are hot issues of academic research. Over-raised capital is not a unique phenomenon in China's capital market, but also exists in the capital markets of developed countries and other emerging capital markets. At the beginning of the phenomenon, many Western scholars carried out relevant studies, and domestic scholars have also paid more attention to this phenomenon in recent years. Studies at home and abroad focus on two aspects: one is whether IPO is related to the acquisition of over-raised capital; the second is the impact of over-raised capital on the management of the company.

As for the motivation, the mainstream literature abroad shows that over-raised capital is one of the important reasons for a company's IPO. Taggart (1997) found that when the market overvalues companies, companies are more willing to issue stocks for financing, which reflects that the main purpose of issuing stocks is to obtain overraised capital. Pagano et al. (1998) took Italian companies as the research samples and found that most company's purpose of IPO is not to raise captital for projects, but to obtain over-raised capital and balance capital structure. Woojin and Weisbach (2008) used 17,226 newly-issued shares and 12,373 refinancing shares as samples to investigate the use of initial capital raising and refinancing capital, and found that one of the motivations for companies' IPO was to obtain over-raised capital through market mispricing.

*Corresponding author's e-mail: 739960103@qq.com
As for the influence of of over-raised capital on the management of the company, most literatures believe that it has a negative effect. Jiang Xin and Li Quan (2010) theoretically explained the harm of over-raising, believing that it is difficult to make efficient investment with overraised capital, which is usually deposited in the bank to collect interest or invested in blind projects, and there is also the possibility of misappropriation of over-raised capital.

Lu Junsheng et al. (2012) studied GEM listed companies in China and found that the over-raised capital ratio has a significant negative impact on the growth rate of earnings of per share and return on equity.

Xia Yun and Xu Xin (2012) took the IPO companies in Shenzhen A-share market from 2006 to 2010 as samples, and found that there were serious over-investment behaviors in the use of IPO over-raised capital by listed companies, and the internal governance mechanism of companies could effectively alleviate the agency problem in the use of IPO over-raised capital.

Cao Guohua and Liao Xinyi (2016) discussed the impact of IPO over-raised capital on the inefficient investment behavior of listed enterprises. The study found that the more over-raised capital, the greater the degree of over-investment or underinvestment.

Research at home and abroad shows that venture capital has "attestation" and "supervision" effects on the enterprise. On the one hand, before investment, the risk investment institutions make all-round investigation and assessment to select out the potentially prosperous enterprise. Therefore, to other outside investors, the involvement of venture 
capital means the attestation to the enterprise, and investors are willing to raise IPO price (Gompers and Lerner, 1999); On the other hand, after investment, venture capital institutions often actively supervise company management by appointing excutives (Barry et al.,1990).

Obviously, the " attestation" and "supervision" roles of venture capital help to reduce information asymmetry and increase investor's recognition, thus raising IPO pricing(Gorman and Sahlman,1989; Megginson and Weiss, 1991; Chen Gongmeng,et al., 2011; Zhang Xueyong et al., 2011; Chen Wei et al., 2013; Qu Guojun et al., 2017).

Research shows that venture capital plays an important role in company governance. However,the influence of venture capital on IPO over-raising capital of enterprises is rarely covered in the existing literature, to which this paper makes a beneficial attempt.

\section{Theoretical analysis and research hypothesis}

The research shows that venture capital has a supervisory effect on the invested enterprises. Different from other capital providers, venture capital institutions are professional investment institutions. In addition to providing equity capital, they also supervise the invested enterprises by participating in the board of directors. They often use some incentive, punishment, restraint and management means to supervise the management of the invested enterprise, so as to reduce the conflict of objectives, unify the interests of both sides and promote the long-term development of the enterprise. However, it is difficult to find suitable investment projects in a short period of time due to the huge amount of over-raised capital, resulting in the enterprise to keep more cash. The existence of the principal-agent problem makes the capital likely to be invested in low-efficient or even no-efficient projects. As professional investment institutions, venture capital institutions will give full play to their professional advantages from the perspective of maximizing their own interests, optimize the investment and financing decisions of the target company, improve the efficiency of the use of raised capital, and reduce the over-raised capital ratio. Therefore, we propose the first research hypothesis:

Hypothesis 1: Compared with the listed companies without venture capital support, the over-raised capital ratio of the ones with venture capital support is relatively low.

Venture capital institutions are often willing to enter some enterprises with large asset scale and high quality, because these enterprises have relatively low degree of information asymmetry and relatively perfect company governance. However, companies with small asset scale often have relatively higher degree of information asymmetry and more imperfect company governance. Therefore, investors face a greater risk when investing companies with small asset scale. If the small enterprises want to attract venture capital, they often tends to transfer their own control right, which usually results in risk investment institutions' more seats in the board of directors, providing better supervision over the enterprises.

Therefore, compared with large enterprises, venture capital institutions have more strict supervision over small enterprises, which has a greater impact on the IPO of invested enterprises, resulting in a lower over-raised capital ratio of small enterprises. Thus, we propose the second research hypothesis:

Hypothesis 2: Compared with large listed companies, venture capital can reduce over-raised capital ratio of small listed companies.

\section{Research design}

\section{1 samples and data sources}

This paper chooses IPO companies in Shenzhen Small and medium-size Enterprise (SME) as samples from 2009 to 2018. In sample selection, we excluded the following types of enterprises: (1) financial and insurance companies; (2) companies that have been listed by ST and *ST; (3) companies with missing relevant data. At last, 639 observations were obtained in this paper. The financial data and market transaction data needed for the research were obtained from the Wind and CSMAR databases.

Whether the listed company is backed by venture capital institutions is judged by the following standards: before an initial public offering, if the name of any of the company's top ten shareholders includes the word "investment", then, the shareholder's business background should be checked according to the Description of the Evolution of the Share Capital. As long as the shareholder engages in the venture capital investment, venture investment, equity investment, then, the listed company is regarded as venture capital backed one.

\subsection{Variable selection and model setting}

\subsubsection{Variable selection}

The dependent variable of the econometric analysis in this paper is O_Ratio, which is the ratio of the over-raised capital to the planned raised capital. The calculation formula is as follows:

$$
\mathrm{O} \_ \text {Ratio }=\left(N \text { et } \_F \text { und }-P_{-} F \text { und }\right) / P_{-} \text {Fund }
$$

In the formula, Net_Fund is the net raised capital after deducting the issuance expenses, and P_Fund is the planned raised capital. The explanatory variable in this paper is $\mathrm{Vc}$, the dummy variable of venture capital. If the listed company is backed by venture capital, then, $\mathrm{Vc}$ is set as 1 ; otherwise, as 0 .

In order to accurately measure the relationship between dependent variables and explanatory variables, this paper selects the following control variables with reference to existing studies: (1) earnings per share; (2) Cash flow from operating activities per share; (3) asset-liability ratio Lev; (4) the Growth rate of operating income, an alternative indicator reflecting the Growth of enterprises; (5) Size of the company, using the natural logarithm of the total assets as the substitute variable of the company Size; (6) shareholding ratio of the largest shareholder. The above data are based on the data of the year prior to the initial 
public offering of the listed company; (7) Size of the board of directors; (8) independence of the board of directors; (9) dummy variable Duality of Chairman and general manager; (10) market Return on the first day in the market, the substitution variable reflecting the market-heat; (11) reputation of underwriters Undwr, In this paper, the market share of each underwriter in the securities underwriting market is taken as a measure of the reputation of the underwriter. The higher the market share, the higher the reputation of the underwriter. If the top ten underwriters are the main underwriters, then, Undwr is set to 1; otherwise, 0 . (12) IndustryDummy variable. The annual dummy variable is not controlled because all the data in this paper are the data of the year before the listing of the listed company, and the data of different years of the same company are not involved. See table 1 for the definition of each variable.

Table 1: the definition of each variable

\begin{tabular}{|c|c|}
\hline variable name & Variable definition \\
\hline O_Ratio & the ratio of the over-raised capital to the planned raised capital \\
\hline $\mathrm{Vc}$ & $\begin{array}{l}\text { the dummy variable of venture capital. If the listed company is backed by } \\
\text { venture capital, then, } \mathrm{Vc} \text { is set as } 1 \text {; otherwise, as } 0 \text {. }\end{array}$ \\
\hline Eps & earnings per share, i.e. earnings per share in the year before the IPO \\
\hline Cash & $\begin{array}{l}\text { Cash flow from operating activities per share, i.e. Cash flow from } \\
\text { operating activities per share in the year before the IPO }\end{array}$ \\
\hline Lev & $\begin{array}{l}\text { asset-liability ratio Lev, i.e. asset-liability ratio in the year before the } \\
\text { IPO }\end{array}$ \\
\hline Growth & $\begin{array}{l}\text { the Growth rate of operating income, i.e. the Growth rate of operating } \\
\text { income in the year before the IPO }\end{array}$ \\
\hline Size & $\begin{array}{c}\text { Size of the company, i.e. the natural logarithm of the total assets in the } \\
\text { year before the IPO }\end{array}$ \\
\hline Share & $\begin{array}{l}\text { shareholding ratio of the largest shareholder, i.e. shareholding ratio of } \\
\text { the largest shareholder in the year before the IPO }\end{array}$ \\
\hline BoardSize & $\begin{array}{l}\text { Size of the board of directors, i.e. number of board members at the time } \\
\text { of IPO }\end{array}$ \\
\hline Independent & $\begin{array}{l}\text { independence of the board of directors, i.e. the proportion of } \\
\text { independent directors in the board of directors at the time of IPO }\end{array}$ \\
\hline Duality & $\begin{array}{l}\text { Duality of Chairman and general manager, if the Chairman is also the } \\
\text { general manager simultaneously, Duality is set to } 1 \text {, otherwise, } 0 \text {. }\end{array}$ \\
\hline Return & $\begin{array}{l}\text { market Return on the first day in the market, the data is from the } \\
\text { CSMAR database }\end{array}$ \\
\hline Undwr & $\begin{array}{l}\text { reputation of underwriters, according to the ranking of stock and bond } \\
\text { underwriting amount of securities companies published by the securities } \\
\text { industry association of each year (including the ranking of stock and bond } \\
\text { underwriters of securities companies in } 2012 \text { and } 2013 \text { ), If the top ten } \\
\text { underwriters are the main underwriters, then, Undwr is set to 1; otherwise, } 0 \text {. }\end{array}$ \\
\hline IndustryDummy & Industry dummy variable \\
\hline
\end{tabular}

\subsubsection{Model setting}

$$
\begin{aligned}
O_{-} \text {Ratio }_{\mathrm{i}} & =\beta_{0}+\beta_{1} \mathrm{Vc}_{\mathrm{i}}+\beta_{2} \text { Eps }_{i}+\beta_{3} \text { Cash }_{i}+\beta_{4} \text { Lev }_{i}+\beta_{5} \text { Growth }_{i} \\
& +\beta_{6} \text { Size }_{i}+\beta_{7} \text { Share }+\beta_{8} \text { BoradSize }+\beta_{9} \text { Independent } \\
& +\beta_{9} \text { Duality }+\beta_{10} \text { Re turn }+\beta_{11} \text { Undwr }_{i}+\text { IndustryDummy }+\varepsilon_{i}
\end{aligned}
$$




\section{Result analysis}

\subsection{Descriptive statistics analysis}

Descriptive statistics of variables in the study samples are shown in table 2. It can be seen from table 2 that : (1) the average $\mathrm{O}$ Ratio of sample companies is 0.772 times, the maximum O_Ratio is as high as 6.531 times, and the minimum $\mathrm{O}$ Ratio is -0.942 , indicating that some listed companies have not raised the planned raised capital, while some have excessive over-raised capital. (2) among the sample companies, $49.6 \%$ of the listed companies is backed by venture capital, indicating that there are more venture capital institutions holding shares in the Small and medium-size Enterprise (SME) listed company in China.

Table 2 descriptive statistics of variables

\begin{tabular}{|c|c|c|c|c|c|c|}
\hline variable & average & median & maximum & minimum & $\begin{array}{l}\text { Standard } \\
\text { deviation }\end{array}$ & observed value \\
\hline O_Ratio & 0.772 & 0.566 & 6.531 & -0.942 & 1.000 & 639 \\
\hline $\mathrm{Vc}$ & 0.496 & 0 & 1 & 0 & 0.500 & 639 \\
\hline Eps & 0.830 & 0.740 & 2.870 & 0.140 & 0.420 & 639 \\
\hline Cash & 0.846 & 0.780 & 5.3 & -3.240 & 0.776 & 639 \\
\hline Lev & 46.305 & 46.730 & 98.203 & 5.303 & 15.677 & 639 \\
\hline Growth & 19.283 & 15.564 & 411.034 & -35.746 & 29.844 & 639 \\
\hline Size & 20.392 & 20.261 & 24.693 & 18.815 & 0.769 & 639 \\
\hline Share & 51.648 & 51.000 & 97.520 & 7.010 & 18.140 & 639 \\
\hline BoardSize & 8.527 & 9 & 15 & 5 & 1.471 & 639 \\
\hline Independent & 0.368 & 0.333 & 0.600 & 0.222 & 0.495 & 639 \\
\hline Duality & 0.446 & 0 & 1 & 0 & 0.497 & 639 \\
\hline Return & 0.001 & 0.004 & 0.177 & -0.193 & 0.050 & 639 \\
\hline Undwr & 0.365 & 0 & 1 & 0 & 0.482 & 639 \\
\hline
\end{tabular}

\subsection{Mean difference test and median difference test}

We grouped the sample companies according to whether they had venture capital or not, and then investigated the relationship between venture capital and over-raised capital through inter-group comparative analysis. The main methods we used were the inter-group mean ( $T$ test) and median test (Wilcoxon rank-sum test), and the test results were shown in part A of table 3. As can be seen from part $\mathrm{A}$, the average $\mathrm{O}$ Ratio of listed companies backed by venture capital institutions is significantly lower than that of listed companies not backed by venture capital institutions. This test result provides preliminary evidence for hypothesis 1 .

Furthermore, we examine the differences in the relationship between venture capital and over-raised capital among enterprises of different sizes. On the basis of the median size of sample companies, we divided all samples into two subsamples: large companies and small companies. On this basis, we tested the influence of venture capital support and non-venture capital support on over-raised capital in each subsample. The results of part $\mathrm{B}$ in table 3 show that the O_Ratio of listed companies backed by venture capital in the sample of small companies is significantly lower than that of listed companies not backed by venture capital. However, the O_Ratio of listed companies backed by venture capital in large companies is significantly lower than that of listed companies not backed by venture capital, but the significance of large companies is lower than that of small ones. The test results in part $\mathrm{B}$ of table 3 provide preliminary evidence for hypothesis 2 . 
Table 3 comparison and analysis of O_Ratio of listed companies with different size

\begin{tabular}{c|c|c|c|c}
\hline & $\begin{array}{c}\text { Group 1: Vc=0 } \\
\text { Mean (median) }\end{array}$ & $\begin{array}{c}\text { Group 2: Vc=1 } \\
\text { Mean (median) }\end{array}$ & $\begin{array}{c}\text { Average difference } \\
\text { (median } \\
\text { difference) }\end{array}$ & T value (Z value) \\
\hline \multicolumn{5}{|c}{ A: Overall sample } \\
\hline O_Ratio & $0.985(0.838)$ & $0.555(0.081)$ & $0.430(0.767)$ & $5.554^{* * *}\left(5.416^{* * *}\right)$ \\
\hline $\begin{array}{c}\text { Small } \\
\text { company }\end{array}$ & $1.205(1.116)$ & $0.598(0.327)$ & $0.607(0.789)$ & $5.310^{* * *}\left(5.286^{* * *}\right)$ \\
\hline $\begin{array}{c}\text { Large } \\
\text { company }\end{array}$ & $0.721(0.470)$ & $0.520(-0.000)$ & $0.201(0.470)$ & $1.965^{*}\left(2.212^{* *}\right)$ \\
\hline
\end{tabular}

Note: $* * *, * *$ and $*$ mean significant at $1 \%, 5 \%$ and $10 \%$ respectively.

\subsection{Regression analysis}

First, we took all the 639 observed values as samples to make regression estimation for model (1), and the results are listed in table 4 . Column 1 is the regression result under the control of industry dummy variable. We find that the regression coefficient of over-raised capital caused by the involvement of venture capital institutions is significantly negative at the confidence level of $1 \%$. Column 2 controls all variables, and it is found that the involvement of venture capital institutions has a significant negative effect on over-raised capital, and the regression results support hypothesis 1 . Meanwhile, the return coefficients of other variables were in line with expectations.

Table 4 regression results of venture capital and over-raised capital

\begin{tabular}{c|c|c}
\hline \multicolumn{2}{c}{ Dependent variable: O_Ratio } \\
\hline Independent variable & $(1)$ & $(2)$ \\
\hline \multirow{2}{*}{ Vc } & $-0.373^{* * *}$ & $-0.363^{* * *}$ \\
& $(0.000)$ & $(0.000)$ \\
\hline \multirow{2}{*}{ Eps } & & 0.149 \\
& & $(0.156)$ \\
\hline \multirow{2}{*}{ Cash } & & -0.008 \\
& & $(0.874)$ \\
\hline \multirow{2}{*}{ Lev } & & $0.011^{* * *}$ \\
& & $(0.000)$ \\
\hline \multirow{2}{*}{ Growth } & & $0.009^{* * *}$ \\
& & $(0.000)$ \\
\hline \multirow{2}{*}{ Size } & & $-0.437^{* * *}$ \\
& & $(0.000)$ \\
\hline \multirow{2}{*}{ Share } & & -0.000 \\
& & $(0.949)$ \\
\hline \multirow{2}{*}{ BoardSize } & & $0.095^{* * *}$ \\
& & $(0.001)$ \\
\hline \multirow{2}{*}{ Independent } & & 0.019 \\
& & $(0.983)$ \\
\hline
\end{tabular}




\begin{tabular}{c|c|c}
\hline Duality & & 0.004 \\
& & $(0.950)$ \\
\hline \multirow{2}{*}{ Return } & & $-1.355^{* *}$ \\
& & $(0.035)$ \\
\hline \multirow{2}{*}{ Undwr } & & $0.169^{* *}$ \\
& & $(0.025)$ \\
\hline \multirow{2}{*}{ Intercept } & $0.857^{* * *}$ & $8.246^{* * *}$ \\
& $(0.003)$ & $(0.000)$ \\
\hline Industry Dummy & Under control & Under control \\
\hline $\mathrm{N}$ & 639 & 639 \\
\hline R-squared & 0.107 & 0.272 \\
\hline
\end{tabular}

Note: $* * * * *$ and $*$ represent significant at the levels of $1 \%, 5 \%$ and $10 \%$ respectively, and the values in brackets represent the $\mathrm{p}$ value of the $\mathrm{t}$ statistic of the corresponding coefficient.

Then, we further investigated whether there were differences between samples of different sizes in the impact of venture capital on over-raised capital. For this reason, we respectively used model (1) for regression estimation, and the results are listed in table 5. Column 1 is the regression result of over-raised capital when small companies are under the control of industry dummy variable. We find that the regression coefficient of $\mathrm{Vc}$ is significantly negative. Column 2 is the regression result with all variables controlled in small companies. We find that the regression result is similar to that of column 1, and the regression coefficient of $\mathrm{Vc}$ is significantly negative.
Column 3 is the regression result of venture capital's impact on over-raised capital when large companies are under the control of industry dummy variable. We find that the regression coefficient of $\mathrm{Vc}$ is negative, but not significant. Column 4 is the regression result with all variables controlled in large companies. We find that the regression coefficient of $\mathrm{Vc}$ is negative, which is significant at the confidence level of $10 \%$. The above results reflect that the involvement of venture capital institutions has a more significant impact on over-raised capital in small companies, and the regression results support hypothesis 2 .

Table 5 regression results of venture capital and over-raised capital of companies with different sizes

\begin{tabular}{|c|c|c|c|c|}
\hline \multicolumn{5}{|c|}{ Dependent variable: $\quad$ O_Ratio } \\
\hline & $\begin{array}{l}\text { (1) Small } \\
\text { company }\end{array}$ & $\begin{array}{l}\text { (2) Small } \\
\text { company }\end{array}$ & $\begin{array}{l}\text { (3) Large } \\
\text { company }\end{array}$ & (4) Large company \\
\hline \multirow{2}{*}{$\mathrm{Vc}$} & $-0.555^{* * *}$ & $-0.388^{* * *}$ & -0.113 & $-0.184^{*}$ \\
\hline & $(0.000)$ & $(0.000)$ & $(0.299)$ & $(0.087)$ \\
\hline \multirow{2}{*}{ Eps } & & 0.304 & & 0.016 \\
\hline & & $(0.214)$ & & $(0.899)$ \\
\hline \multirow{2}{*}{ Cash } & & 0.116 & & -0.006 \\
\hline & & $(0.445)$ & & $(0.918)$ \\
\hline \multirow{2}{*}{ Lev } & & $0.018^{* * *}$ & & $0.008^{* * *}$ \\
\hline & & $(0.000)$ & & $(0.008)$ \\
\hline \multirow{2}{*}{ Growth } & & $0.006^{* *}$ & & $0.009^{* * *}$ \\
\hline & & $(0.010)$ & & $(0.000)$ \\
\hline \multirow{2}{*}{ Size } & & $-0.954^{* * *}$ & & $-0.359^{* * *}$ \\
\hline & & $(0.000)$ & & $(0.000)$ \\
\hline \multirow{2}{*}{ Share } & & -0.001 & & 0.000 \\
\hline & & $(0.617)$ & & $(0.936)$ \\
\hline
\end{tabular}




\begin{tabular}{c|c|c|c|c}
\hline \multirow{2}{*}{ BoardSize } & & $\begin{array}{c}0.113^{* * *} \\
(0.004)\end{array}$ & & $0.083^{*}$ \\
& & -0.600 & & $0.073)$ \\
\hline \multirow{2}{*}{ Independent } & & $(0.964)$ & & 0.200 \\
& & -0.074 & & $0.880)$ \\
\hline \multirow{2}{*}{ Duality } & & $(0.487)$ & & 0.081 \\
& & -0.971 & & $(0.443)$ \\
\hline \multirow{2}{*}{ Return } & & $(0.324)$ & & $-1.806^{* *}$ \\
& & $0.389^{* * *}$ & & $(0.038)$ \\
\hline \multirow{2}{*}{ Undwr } & & $(0.001)$ & & 0.024 \\
& & $17.947^{* * *}$ & \multirow{2}{*}{0.460} & $6.810)$ \\
\hline \multirow{2}{*}{ Intercept } & $(0.000)$ & $(0.000)$ & & $(0.000)$ \\
\hline Industry & Under control & Under control & Under control & Under control \\
\hline Dummy & 320 & 320 & 319 & 319 \\
\hline R-squared & 0.189 & 0.360 & 0.059 & 0.239 \\
\hline
\end{tabular}

Note: $* * *, * *$ and $*$ represent significant at the levels of $1 \%, 5 \%$ and $10 \%$ respectively, and the values in brackets represent the $\mathrm{p}$ value of the $\mathrm{t}$ statistic of the corresponding coefficient.

\section{Robustness test}

In order to further test the reliability of the results, we conducted the following robustness test and found that the conclusion of this paper does not change on the whole :

First, we substituted earnings per share (Eps) with return on total assets (ROA) and return on equity (ROE) into the regression model and found no substantive impact on the main conclusions of this paper.

Second, We substitute the market return on the first day of listing, a variable that reflects market-heat, with successful rate of cash application and found no substantive impact on the main conclusions of this paper.

\section{Conclusions and suggestions}

Choosing IPO companies in Shenzhen Small and mediumsize Enterprise (SME) as samples from 2009 to 2018, the paper examines the influence of venture capital on overraised capital ratio. The results show that: (1) generally speaking, compared to no venture capital backed companies, those companies backed by venture capital have lower over-raised capital ratio. (2) The interaction effect between venture capital and over-raised capital ratio differs within firms with different size. The impact of venture capital on firm's over-raised capital ratio is more significant for the smaller firms.

The conclusion of this paper has important theoretical significance. At present, domestic and foreign studies rarely discuss the relationship between venture capital and over-raised capital, so this paper is a preliminary attempt. Subsequent studies can further expand to the influence of reputation and ownership characteristics of venture capital institutions on over-raised capital, thus, enriching the theory of venture capital.

The research conclusion of this paper has important policy significance for promoting the reasonable and orderly development of China's capital market and optimizing the financing needs of listed companies.

First of all, with the continuous growth of venture capital institutions in China, venture capital plays an increasingly important role in improving the governance structure of listed companies. Therefore, the regulators should encourage the development of the venture capital industry, appropriately increase the shareholding proportion of venture capital in the listed companies by formulating relevant provisions and make venture capital participate in company governance, making best use of venture capital's beneficial effect on the over-raised capital of enterprises.

Secondly, there are some differences in the effect of venture capital on the over-raised capital of companies with different sizes, especially for small and mediumsized companies. Therefore, for the companies that are going to be listed on SME, GEM or science and innovation board, the regulatory authorities can accordingly increase the provisions in the listing conditions about the shareholding of venture capital institutions so as to give better play to the role of venture capital in company governance.

\section{Acknowledgment}

By the National Natural Science Foundation of China project "venture capital, corporate governance and hightech enterprise investment and financing behavior 
research "(project number :71362007) and Jiangxi Province social science research "11th Five-Year Plan" project "China's over-the-counter market construction path selection and system design "(Jiangxi social planning word [2010]12) funding.

\section{References}

1. Paul A . Gompers, Josh Lerner. What Drives Venture Capital Fundraising . NBER Working Paper, 1999, 6906 .

2. Barry, Christopher B ., Chris J . Muscarella, John W . Peavy III and Michael R. Vetsuypens. The Role of Venture Capital in the Creation of Public Companies: Evidence from the Going-public Process[J]. Journal of Financial Economics, 1990 , 27(2): 447-471.

3. Megginson, William L . and Kathleen A . Weiss . Venture Capitalist Certification in Initial Public Offerings[J] . Journal of Finance, 1991, 46(3): 879-903

4. Michael Gorman, William A . Sahlman . What do venture capitalists do?[J] . Journal of Business Ventuing . 1989, 4(4): 231-248 .

5. Taggart Robert A . A Model of Corporate Financing Decisions[J] . Journal of Finance . 1977, 32 (5): 1467-1484.

6. Pagano Marco, Panetta Fabio and Zingales Luigi, Why Do Companies Go Pubic? An Empirical Analysis[J] . Journal of Finance . 1998, 53(1): 27-64.

7. Woojin Kim, Michael S. Weisbach . Motivations for pubilc equity offers: An international perspective[J] . Journal of Financial Economics . 2008, 87(2): 281-307.

8. Baker, Paul A . Gompers. The Determinants of Board Structure at the Iinitial Pubulic Offering[J]. Journal of Law and Economics, 2003, 46(2): 569-598.

9. Bouresli A.K. ,Wallace N. Davidson III and Fayez A. Abdulsalam. Role of Venture Capitalists in IPO Corporate Governance and Operating Performance[J] . Journal of Business and Economics, 2002, 41(3/4): 71-82 .

10. Brav, Alon and Paul A. Gompers . Myth or Reality? The Long-Run Underperformance of Initial Public Offerings:Evidence from Venture and Nonventure Capital-Backed Companies[J] . Journal of Finance, 1997, 52(5): 1791-1821.

11. Hochberg, Yael V. Venture Capital and Corporate Governance in the Newly Public Firm . Unpublished Working Paper, 2008 .
12. Jiang Xin, Li Quan. Analysis on the Phenomenon of GEM Over-raising Capital [J] . China Financial, 2010(2): 47-49

13. Lu Junsheng, Zhu Yanyang, Wang Weiyi . Study on the Relationship Between GEM IPO Over-raised Capital and Enterprise Performance [R] . International Conference on Engineering and Business Management, 2012 .

14. Xia Yun, Xuxin . Internal Company Governance and the use of IPO Over-raised Capital: from the Study of China's Securities Market [J] . Stock Market Daily, 2012(10): 28-34 .

15. Cao Guohua, Liao Xinyi. Regulatory Effects of IPO Over-raised Capital, Inefficient Investment Behavior of Listed Enterprises and Internal Company Governance $[\mathrm{J}]$. Wuhan Financial, 2016(10): 1620.

16. Chen Gongmeng, Yu Xin, Kou Xianghe . Impact of Venture Capital Participation on IPO Discount of Chinese Companies: A Comparison of Different Securities Markets [J] . Economic Research, 2011(5): 74-85 .

17. Chen wei, Yang Dakai. Impact of Venture Capital Heterogeneity on IPO: Based on Empirical Analysis of SME Board [J]. Journal of Shanxi University of Finance and Economics, 2013(3): 33-43.

18. Qu Guojun, Song Lin, Feng Zhaozhen. Empirical Analysis Based on GEM: Will Venture Capital Reduce IPO Underpricing?[J].Reform of Economic System, 2017(4): 188-195.

19. Deng Yaogang. Impact of Venture Capital on IPO P/E Ratio of Listed Companies: Based on Empirical Analysis of GEM Listed Companies [J].Reform and Opening up, 2010(18): 52-56.

20. Dang xinghua, He Liping, Wang Lei. Canonical Correlation Between the Control Structure of Venture Enterprises and the Growth Ability of Enterprises [J].Soft Science, 2008(4): 136-139.

21. Guo Hong, Zhao Zhenyu.Influence of Underwriter Reputation on IPO Company 's Pricing, Initial and Long-term Returns [J].Management World,2006(3) 122-128.

22. Xu Haoping, Luo Wei.Effectiveness of the Reputation Mechanism of Investment Banks: from the Dual Perspectives of Practice Quality and Market Share [J].Economic Research, 2007(2): 124-136 .

23. Tan Yi, Ye Cen.Analysis of Venture Capital's Efficiency in Company Governance Structure [J]. Chinese Soft Science,2001(4): 46-51.

24. Wu Chaopeng, Wu Shinong, Cheng Jingya, Wang $\mathrm{Lu}$. Impact of Venture Capital on the Investment and Financing Behavior of Listed Companies [J]. Economic Research, 2012(1): 105-119.

25. Zeng Jjianghong, Yang Kaifa.Impact of Venture Capital on IPO Underpricing: Based on the Empirical 
Study of China's SME Board Listed Companies [J].Economy and management Research, 2010(5): 33-39.

26. Zhang Xueyong, Liao Li. Venture Capital Background and IPO: Market Performance and Internal Mechanism [J]. Economic Research , 2011(6): 118-132.

27. Zhang Yichun, Hong Tu.Influencing Factors of GEM IPO P/E Ratio and O Ratio: Based on Empirical Analysis of Broker's Reputation and Private Equity Investment [J].Journal of Xiamen University (Philosophy and Social Sciences Edition), 2012(3): 42-49 . 